\title{
A DEMOCRACIA NO BRASIL: um confronto entre as principais perspectivas teóricas na primeira metade do século $X X$.
}

\section{Maria José de Rezende*}

\begin{abstract}
Este artigo é uma reflexão sobre as principais correntes de pensamento que se debatiam na primeira metade do século XX, no Brasil, em torno da questão da democracia. Apontou-se, porém, alguns elementos desta problemática no final do século XIX como uma forma de apreender os aspectos que a rigor se constituíram em dados esclarecedores dos rumos que o debate assumiu no período aqui analisado.
\end{abstract}

Palavras-chave: Brasil; Democracia; Público; Privado; Autoritarismo; Personalismo.

$\mathrm{S}$ érgio Buarque de Holanda afirma em Raízes do Brasil que a democracia enquanto ideal ou como prática política já nasceu aqui como um lamentável mal-entendido. ${ }^{10}$ "A democracia que nasceu aqui num mal-entendido percorreu em nossa história um caminho inusitado"(HOLANDA, 1976).

A democracia tem assumido no Brasil, desde remotos tempos, um significado singular. No século XIX, diversos políticos tidos como liberais na época do império afirmavam seus anseios por uma democracia de "gravata lavada". Sérgio Buarque de Holanda cita Teófilo Ottoni que dizia: "o que eu quero é a democracia de classe média, a democracia de gravata lavada" (HOLANDA, 1976: 4).

Uma parte significativa das análises da forma de organização da política brasileira desde os seus primórdios tem destacado a ausência de condições mínimas para a existência da democracia no Brasil.

Alguns trabalhos que podem ser considerados clássicos como Os donos do poder de Raymundo Faoro, Coronelismo, enxada e voto de Victor

* Prof do Departamento de Ciências Sociais da Universidade Estadual de Londrina

${ }^{10}$ Ressalte-se que Sérgio Buarque de Holanda está criticando a maneira como diversos pensadores brasileiros utilizavam o conceito de democracia importando-o e empregando-o de forma desconectada com a nossa realidade. A democracia como um malentendido é a expressão da confluência de falta de bases econômicas, políticas, culturais e sociais, tanto para a sua existência quanto pela "facilidade com que se alimentam (alguns intelectuais) de doutrinas dos mais variados matizes e com que sustentam, simultaneamente, as convicções mais díspares." (HOLANDA, 1987, p. 113)
Nunes Leal, Raízes do Brasil de Sérgio Buarque de Holanda, A ordem privada e a organização política nacional de Nestor Duarte, dentre outros, destacam o enorme vigor do poder privado no Brasil desde os tempos coloniais; o qual se cristalizou como um verdadeiro empecilho para a democratização do país ${ }^{11}$.

Raymundo Faoro, em Os donos do poder, mostra que a formação do Estado brasileiro e a forma de domínio patrimonial e burocrática que adentraram no âmago da organização política e administrativa brasileira, desde a época da colônia, conduziram a uma exorbitante centralização política e a uma combinação de privatismo e arbítrio que resultaram em "exercicio privado de funções públicas e (...) exercício público de atribuições não legais"(FAORO, 1989:182).

Repousariam aí os elementos constituintes da exclusão do povo do sistema político brasileiro. No entanto, essas raízes foram potencializadas nos periodos subseqüentes. Na época do império, afirma Faoro, já estava delineada, através da constituição de 1822 , a tentativa de equilíbrio entre liberdade e poder executivo forte.

Em A democracia coroada, João Camillo Torres publica um depoimento do imperador $\mathrm{D}$. Pedro I, por ocasião do debate sobre a constituição de 1822 , em que este último propunha, segundo Torres, um sistema constitucional que operasse uma

\footnotetext{
11. Serão citados aqui diversos trabalhos que destacaram direta ou indiretamente a questão da democracia no século XIX. No entanto, reconhece-se que há diferenças significativas de ordem teóricometodológicas entre eles, as quais não serão abordadas.
} 
fusão da monarquia, da aristocracia e da democracia. $^{12}$

Caio Prado Júnior analisa, em Evolução política do Brasil: colônia e império, as forças políticas do Império e demonstra como, no embate entre as mesmas, assiste-se à emergência de uma idéia abstrata de liberdade e de democracia (PRADO Jr, 1987 , p. 57). Fica evidente que, para ele, somente a partir das lutas que cortam horizontal e verticalmente a sociedade brasileira, naquele momento, torna-se possível captar a singularidade da concepção de democracia que estava tomando corpo.

Durante o primeiro reinado, afirma Caio Prado Júnior, era detectável que os grandes proprietários rurais que faziam oposição politica ao imperador, tentavam ganhar confiabilidade (das classes não abastadas) para uma idéia de democracia absolutamente indefinida.

No entanto, faz-se necessário observar que, para Caio Prado Júnior, não apenas a classe mais abastada tomava a democracia como algo eminentemente abstrato, mas também os setores médios. A oposição democrática radical do primeiro reinado, chamada ala esquerda do partido nacional, da qual participavam apenas os setores médios (PRADO Jr, 1987, p. 66), deixava isto evidente ao retroceder diante da menor possibilidade de que as camadas inferiores entrassem em ação.

No segundo reinado, segundo Faoro, já estariam delineadas as marcas das ambigüidades tanto do liberalismo quanto da democracia, no Brasil. Havia uma conciliação do liberalismo ${ }^{13}$ com o poder monárquico, mas não seria possível ignorar a existência de uma ala liberal de esquerda (Jornal Opinião Liberal) (FAORO, 1989, p. 447) que identificava liberalismo e democracia.

Os denominados liberais radicais (Rangel Pestana, Luiz Monteiro de Souza, Limpo de Abreu) defendiam a soberania do povo e, portanto, eram qualificados de democratas. Ficava evidenciada a ambigüidade de suas posições sobre a democracia à medida que eles queriam salvar a monarquia através de apelos à democracia, dizia Faoro.

No império, afirma Sérgio Buarque de Holanda, ocorreram várias mudanças superficiais, e dentre elas estava a tentativa de "vestir um país ainda preso à economia escravocrata, com os trajes modernos de uma grande democracia burguesa" (HOLANDA, 1987, p. 46).

\footnotetext{
${ }^{12}$ TORRES, J. C. de Oliveira A democracia coroada. Rio de Janeiro, J.Olympio, 1957. p.498 et seq."E não é preciso redizer que designações tais como democracia e democracia coroada, empregadas com notável insistência pelos apologistas da Monarquia brasileira, são totalmente inadequadas com a significação que, nesse caso, thes é atribuida." (HOLANDA, 1972, p. 72-78).

${ }^{13}$ Em entrevista de 1976, Raymundo Faoro afirma que deveria ter feito uma crítica mais contundente ao liberalismo no livro Os donos do poder. "No livro fui condescendente com os liberais. $\mathrm{Na}$ verdade, acho que aceitei o mito liberal - um desses mitos que a maioria de nós engoliu." FAORO, R. Romance sem heróis. Veja, São Paulo, n.399, p.6, 28 abr. 1976.
}

A possibilidade de uma democracia nestes termos estava na forma de concebê-la, ou seja, como uma democracia de exclusão que se expressava no desprezo pelas classes populares. Para exemplificar, Sérgio B. de Holanda cita Frei Caneca que afirmava: "É impossível viver com esta gentalha composta de mulatos e mestiços." (HOLANDA, 1976).

Sérgio Buarque de Holanda destaca também que a palavra democracia era mal vista pelos liberais brasileiros no começo do império. Quando ganhou status, em meados do império, ela significava liberalismo, ou se confundia com ele (HOLANDA, 1976).

Na nossa história, afirma o autor de Raizes do Brasil, sempre prevaleceram as relações políticas de caráter privado. A partir de 1889 , a casa de cada família de fazendeiros era uma verdadeira república privada. $\mathrm{Na}$ sociedade colonial, a esfera da vida doméstica definia princípios de autoridade tão fortes que conseguiam barrar as forças que a atacavam, deixando evidente que o princípio de autoridade cercava-se por todos os lados de uma teia de relações pautadas no personalismo.

Assiste-se nas obras de Sérgio Buarque de Holanda ${ }^{14}$ à explicitação da enorme impossibilidade de publicização, no Brasil, das relações sociais e políticas. Isto tem perpassado toda nossa história como um alimento que embasou a estruturação de uma sociedade que iria elevar o autoritarismo às alturas.

As indagações sobre a democracia ganhavam uma conotação inusitada à medida que esta ia sendo moldada pelas idéias do liberalismo ${ }^{15}$ e de suas singularidades na sociedade brasileira, do progresso, do abolicionismo, etc., as quais ganharam proeminência a partir de meados do século XIX.

Em Campanha abolicionista no Recife (NABUCO, 1885, p. 12), Joaquim Nabuco afirmou que 0 centro de todo problema brasileiro era a escravidão, a qual tinha já degradado toda a nação, gerando uma inferioridade moral indescritível. Desta forma, dizia ele, em Minha formação, "a grande questão para a democracia brasileira não é a monarquia, é a escravidão." (NABUCO, 1976, p. 115)

A abolição resolveria, segundo Nabuco, o problema maior que envenenava a sociedade brasileira. Apenas a partir dela seria possível reverter o quadro de extrema desigualdade social, ignorância e degradação. A deformação de nossas instituições políticas só poderiam ser resolvidas com a destruição do regime social da escravidão. “(...) a nação

\footnotetext{
${ }^{14}$ HOLANDA,S.B.de. Caminhos e fronteiras. Rio de Janeiro, J.Olympio, 1957; Monções. São Paulo, Alfa-ômega, 1976.; Raízes do Brasil. Rio de Janeiro, J.Olympio, 1987 e História geral da civilização brasileira. São Paulo, t. 1,v.2; t.2,v.2; t.2,v.5; Difel, 1960, 1964, 1972

is Sabre o liberalismo no século XIX, ver NOGUEIRA, 1984.
} 
está convencida de que a escravidão é a causa de todos os seus vícios políticos e fraquezas sociais" (NABUCO, 1949, p. 94).

A dificuldade da democracia brasileira estava associada, para Nabuco, aos nossos vícios políticos que advinham da escravidão como um regime social que não criou uma elite dirigente capaz de conduzir adequadamente as funções públicas.

O sistema representativo no Brasil era a expressão, afirmava $\mathrm{Nabuco}^{16}$, de que a escravidão havia tudo maculado. Este não era mais que um "enxerto de formas parlamentares num governo patriarcal, e senadores e deputados só tomam a sério o papel que lhes cabe nessa paródia de democracia pelas vantagens que auferem"(NABUCO, 1977, p. 170).

Não era possível, afirma Nabuco, chegar à verdadeira democracia num regime social de escravidão, uma vez que ela impossibilitava a existência de um regime representativo de fato, tornando o governo uma casta e a nação sem povo.

A indefinição do significado da democracia no século XIX ficava evidenciada nos escritos de Joaquim Nabuco. Ora a democracia era tomada como um processo em curso no país, mesmo antes da abolição, ora a democracia não era possível devido à existência da escravidão como um regime social e ora a democracia só seria possível num momento posterior, porque esta estaria fundada na atuação política de um operariado que ainda não conhecia sua força, etc. ${ }^{17}$

No debate sobre 0 abolicionismo, o liberalismo, a monarquia e sua crise, no final do século XIX, estava presente a questão da democracia de forma estranhamente colocada. Em termos gerais, ela vinha associada à liberdade "como forma de chegar ao bem do povo" como afirma Faoro em Os donos do poder (FAORO, 1989, p. 513), ou seja, como uma idéia abstrata.

Reconhece-se que é impossível compreender substancialmente a peculiaridade das discussões sobre democracia no século XIX sem uma análise detalhada do liberalismo no Brasil naquele momento, o que não poderá ser feito no âmbito deste trabalho. Foram considerados aqui apenas alguns elementos visando dar uma rápida idéia de um debate que recorria constantemente à democracia numa perspectiva indefinida e abstrata.

Segundo Sérgio Buarque de Holanda o liberalismo no Brasil sempre sobreviveu sem a prática da democracia e, de fato, o próprio liberalismo era

\footnotetext{
${ }^{16}$ Gilberto Freyre, em Interpretação do Brasil, afirma que as posições de Joaquim Nabuco, por exemplo, expressam uma força democrática que nasceu no interior do velho sistema agráriopatriarcal brasileiro. Ou seja, para ele, Joaquim Nabuco era a expressão da tradição brasileira que combinava tendências democráticas e aristocráticas (FREYRE, 1947, p. 118).

${ }_{17}$ Estas indefinições podem ser encontradas em inúmeros textos de Nabuco. Ver: BEIGUELMAN, P. Joaquim Nabuco. São Paulo, Ática, 1982. p. 92, 95, 119, 126, 137.
}

muito capenga. Para ele, "alguns políticos mais lúcidos perceberam isso já no século passado. $\mathrm{Na}$ buco de Araújo, em 1869, dizia que nós tínhamos liberdade, ou liberalismo, mas só nas capitais. No interior, quem resolvia era o capanga, o prefeito ou o chefe de polícia. Em um discurso particularmente inflamado, chegou a afirmar que a liberdade existe para nós, homens de gravata lavada, e não para o povo"'(HOLANDA, 1976:4).

Ressalte-se que a partir da república o processo de esvaziamento da democracia prosseguiu, diz Sérgio Buarque de Holanda. O censo literário foi uma forma de barrar a possibilidade do voto do analfabeto. $\mathrm{E} o$ argumento, diz ele, era o seguinte: nem todos estavam preparados para o jogo democrático.

Raymundo Faoro afirma que a democracia continua tendo um sentido muito peculiar nos primeiros anos da República. Ruy Barbosa se referia a uma necessária estabilidade republicana fundada numa democracia laboriosa e robusta (FAORO, 1989 , p. 517). O sentido de democracia laboriosa estaria no fato de que a mesma deveria ser baseada na indústria e, portanto, oposta aos interesses aristocráticos e monárquicos.

No âmbito das dissensões políticas crescentes entre os componentes do grupo dirigente, durante a primeira república, a democracia vai assumindo feições cada vez mais imprecisas e inusitadas. A candidatura Hermes da Fonseca era exemplo disto. O salvacionismo militar surge "para, em nome da democracia e da pureza representativa, libertar o povo escravizado aos oligarcas. O militar (...) aju$\mathrm{da}$ (ria) os oprimidos a conquistar o poder, manchado de vinte anos de corrupção e violências." (FAORO, 1989, p. 517).

São inúmeros os casos que poderiam ser relacionados para caracterizar as condições políticas vigentes na primeira república, visando captar a trajetória inusitada das pressuposições em torno da democracia. No entanto, não é possível, no âmbito deste trabalho, perseguir todo o processo político daquele momento para apreender o sentido e/ou significado diverso que a democracia ia assumindo.

Considera-se, todavia, que é imprescindível destacar que no início do século $\mathrm{XX}$, mais precisamente até o final da década de 1920 , floresceram inúmeras reflexões que serviriam de base para a problematização em torno da democracia; dentre elas, pode-se citar: a necessidade de criação de uma consciência nacional e de uma dada organização social (TORRES, 1978), a crítica ao liberalismo no Brasil que se confundia com o caudilhismo local ou provincial (VIANNA, 1922) e a insistência de que a elite estaria incumbida de realizar um grande projeto devido à sua superioridade racial (VIANNA, 1982).

Nos anos 20, as discussões sobre as tendências políticas, étnicas e sociais trazem para o plano 
político debates a respeito de: centralização, unidade nacional, democracia, etc., tendo como pano de fundo a problemática da identidade cultural.

Na segunda década do século $X X$ tem início um período nacionalista. A questão étnica foi largamente destacada como fator importante na fundação de um país cultural e politicamente diverso. A criação de uma consciência nacional, tema fundamental nas discussões da segunda década deste século, ligava-se à necessidade de alcançar uma dada organização social e política.

Alberto Torres, em 1914, no livro A organização nacional (TORRES, 1978) expressou com veemência essa preocupação. Ele destacava a necessidade de uma organização nacional a partir da convicção de que convinha ao Brasil um governo autoritário e/ou elitista. O fortalecimento do poder central, defendido por ele, era uma crítica à forma que tomava o federalismo estabelecido em 1891 (TORRES, 1978, p. 162).

O país, afirmava Alberto Torres, possuía apenas um rótulo jurídico de nação. A organização de nossa nacionalidade tinha que ter, para ele, proeminência sobre a organização do país como instituição jurídica. Criticando o liberalismo, ${ }^{18}$ ele afirmava que um governo forte tinha a incumbência de desenvolver o indivíduo e coordenar a sociedade (TORRES, 1978, p. 168-172).

Alberto Torres caracterizava criticamente o regime político daquele momento como democrático. "A oligarquia democrática explora a vida pública, no Brasil, com o mesmo desembaraço que os senhores punham em explorar seus vassalos"(TORRES, 1978, p. 173). A insuficiência e a desordem da administração e da política, assinalava Torres, eram mais que suficientes para convencer a todos da necessidade de um "governo fortíssimo".

Assiste-se, com Alberto Torres, à defesa da idéia de que "para a nossa civilização, sob um regime político democrático, que se propõe a realizar o governo do povo pelo povo, o dever elementar do Estado é formar o povo." (TORRES, 1978, p. 229). Criticando a democracia política, este autor afirmou que esta era apenas uma conquista parcial. "Obra da burguesia do dinheiro e das letras, ela realizou a ascensão desse novo poder, consagrando expressamente, para todos, os direitos de que estes careciam, e que reclamavam; direitos que, assim outorgados à massa proletária e miserável, nada thes conferindo que fosse realmente prático, não as elevaram, também, ao nível do seu oficioso patrono e porta voz." (TORRES, 1978, p. 229).

\footnotetext{
${ }^{18}$ Sobre a posição de Alberto Torres de que o liberalismo era algo alheio à nossa sociedade, ver:

PÉCAUT, D. Os intelectuais e a política no Brasil. São Paulo, Ática, 1990. p.28.
}

A questão da democracia, na obra de Alberto Torres, é algo que gravita em torno da necessidade de organização social. Para ele, sem resolver esta última, não haveria nenhuma possibilidade de se reportar àquela primeira; assim, o regime democrático implantado com a república federativa era desconetado de nossa realidade sob todos os aspectos.

A obra de Oliveira Vianna expressava um diálogo com os elementos levantados por Alberto Torres. Juntamente com a discussão sobre a necessária organização nacional, ganha fôlego na década de 20 a crítica ao liberalismo. Este foi um dos temas tratados por Oliveira Vianna, no livro 0 Idealismo da Evolução do Império e da República, de 1922. A ênfase recaía na argumentação de que o liberalismo correspondia a outros cenários, mas seu significado era totalmente modificado no Brasil, à medida que se confundia com o caudilhismo local e provincial.

As críticas ao liberalismo, naquele momento, elucidam o caminho que tomou, nos anos seguintes, a crítica à democracia liberal. Nos anos 20 já se definiam concepções de democracia centradas na relação massa/elite que prosperou na década seguinte. O elitismo ${ }^{19}$ assume proporções significativas com Oliveira Vianna, Azevedo Amaral, Alceu Amoroso Lima Sobrinho e todo movimento católico daquela época.

Os teóricos brasileiros partidários dessa concepção tinham a convicção de que a elite estaria incumbida de realizar um grande projeto e isto era justificado, principalmente, com base na idéia de superioridade e inferioridade racial. Oliveira Vianna, no livro Populações Meridionais do Brasil, 1920 , discute o conceito de raça visando justificar tanto a superioridade quanto a inferioridade de indivíduos e grupos.

Ressalte-se que era visível a influência dos clássicos da teoria elitista (Robert Michels, principalmente) sobre Oliveira Vianna. A sua análise da forma de organização da democracia no Brasil encontra-se fincada naquelas pressuposições que advogavam uma forma de democracia realizada e conduzida por uma elite no governo.

Enfaticamente, afirmava Oliveira Vianna: "O nosso grande problema, como já disse alhures, não é acabar com as oligarquias; é transformá-las fazendo-as passarem da sua atual condição de oligarquias broncas para uma nova condição - de

\footnotetext{
19 Daniel Pécaut diz que o elitismo não foi, no entanto, "apanágio exclusivo dos nostálgicos de um Estado todo poderoso, nem da ordem cristã". Os liberais também estavam convencidos da necessidade de criar uma elite para conduzir o processo de modernização. Ele cita Fernando de Azevedo que afirmava: "'a democracia consiste, praticamente, não no 'governo do povo pelo povo', o que, em última análise, é uma ficção, mas no governo por elementos 'diretamente' tirados do povo e preparados pela educação. Não há salvação para a democracia senão na escolha e pela escolha de capacidades."' AZEVEDO apud PÉCAUT, op. cit, p.30.
} 
oligarquias esclarecidas. Estas oligarquias esclarecidas seriam então, realmente, a expressão da única forma de democracia possível no Brasil; porque realizada na sua forma genuína, isto é, no sentido ateniense - do governo dos melhores." (OLIVEIRA VIANNA, 1987, p. 137)

A oligarquia esclarecida deveria realizar a democracia no Brasil. Era absolutamente excessivo acreditar que o povo-massa, afirma Oliveira Vianna, pudesse governar, uma vez que este não possuía educação democrática. Para ele, o nosso povomassa não só não estava à altura de uma democracia de massa como nunca a tinha requisitado.

Um de nossos maiores males, para Oliveira Vianna, era a crença num igualitarismo exagerado. "E esta preocupação uniformista e igualitarista que dá a mesma capacidade eleitoral ao sertanejo da Cachoeira do Roberto (cujo nível de vida e de cultura é o mais miserável do mundo, segundo Luetzellburg) e ao cidadão do Rio ou da Paulicéia, instruído, lido em jornais, socializado pelo sindicato de classe, conhecendo a assistência do governo, as instituições de previdência e os seus favores -; é esta preocupação uniformista e igualitarista que tem feito fracassar as experiências de democracia no Brasil, desde 1824." (OLIVEIRA VIANNA, 1987 , p. 143).

Oliveira Vianna afirmou que as classes economicamente superiores deveriam participar com preponderância numa democracia que se tornaria sólida com base num executivo forte e num judiciário ainda mais forte. $\mathrm{O}$ poder legislativo teria importância secundária. Criticando a democracia liberal que cultuava de maneira fetichista a lei e, portanto, queria implantar a democracia no Brasil por decreto, ele argumentava que os liberais não levavam em conta que o povo brasileiro nunca tinha tido escolas (sindicatos, cooperativas, ligas, sociedades, regime de difusão ou propaganda pelo rádio, etc.) que o preparassem para a democracia. Sem esta preparação, diz Oliveira Vianna, "nenhuma espécie de democracia será possível aqui - e é justamente a falta destas condições preparadoras que mais tem concorrido para que a democracia por eles (democratas liberais) instituída no Brasil seja apenas uma democracia de ficção - uma democracia cenográfica (...)."(OLIVEIRA VIANNA, 1987, p. 148).

Tornar realidade a democracia no Brasil passava, para Oliveira Vianna, pela organização da liberdade civil e individual e não pela generalização do sufrágio universal. Ou seja, numa sociedade em que o povo-massa não tem nenhuma garantia efetiva de suas liberdades civis, a decretação do sufrágio universal não passa de um idealismo democrático, afirma.

Para Oliveira Vianna era preciso esquecer a idéia de implantar aqui uma democracia do tipo inglês, pois isto era não só absurdo mas também impossível. Em $\mathbf{O}$ idealismo na constituição, (OLIVEIRA VIANNA, 1927) ele afirmava que a nossa reforma política passava pela organização de instituições especificas, um sistema de freios e contrafreios para neutralizar o espírito de clã que contaminava todo organismo políticoadministrativo.

A liberdade e a democracia adviriam somente a partir deste processo. A ação do Estado era mostrada, por ele, como fundamental para operar as modificações necessárias na estrutura social brasileira. Com 0 Idealismo na Constituição, Oliveira Vianna ajudava a "desmoralizar ainda mais a 'democracia liberal', assim servindo ao mesmo tempo, e sem paradoxos, aos direitistas, esquerdistas e centristas de todos os matizes temporariamente unidos no mesmo esforço para destruir a república 'carcomida' de 1891." (MARTINS, 1978, p. 410).

Eram inúmeras as discussões em torno da questão da democracia no final da década de $20^{20}$ e início da década de 30 . Destaque-se que ganhava proeminência 0 ataque à democracia liberal. $\mathrm{O}$ amplo debate sobre a crise da democracia ${ }^{21}$ feito na Europa era utilizado, no Brasil, como forma de explicar a nossa realidade.

Wilson Martins afirma que diversos intelectuais brasileiros transportaram para o Brasil questões e soluções totalmente desconectadas dos nossos problemas. O exemplo mais evidente era a discussão baseada em Vilfredo Pareto, segundo o qual, a massa destruía a possibilidade de democracia (MARTINS, 1978, p. 40-41). Menotti del Picchia, em 1931, afirmava em A crise brasileira que a democracia era totalmente incompativel com a nossa cultura, naquele momento.

Não sendo possível, no âmbito deste artigo, dar conta das inúmeras discussões sobre a democracia que floresceram nas décadas de 30 e 40 , serão ressaltados os aspectos principais das análises de Azevedo Amaral, Gilberto Freyre e Sérgio Buarque de Holanda quanto à problemática específica da democracia, uma vez que sob perspectivas distintas eles marcaram de forma significativa o debate naquele momento.

\footnotetext{
20 Vicente Licinio Cardoso, em À margem da história do Brasil, obra que reúne vários de seus artigos do final da década de 20 , publicou um texto denominado Democratização pela terra onde tentava sintetizar os percalços da democracia no Brasil desde o imperio. Dentre eles, estava a inexistência de partidos políticos por falta de: idèias orgânicas, programas construtores e equacionamento dos problemas sociais e econômicos. Esses males teriam assolado tanto o império quanto a república. A pobreza franciscana da nossa política comprometia qualquer possibilidade de democracia. (CARDOSO, 1979, p. 98).

${ }^{21}$ Houve ainda, nos anos 30, uma ampla discussão sobre o tipo de democracia que se deveria implantar no Brasil: o modelo americano ou o modelo dos tratadistas franceses. Gilberto Amado, em Espirito do nosso tempo, observava que o ideal seria seguir o modelo norte-americano.
} 
Wilson Martins em História da Inteligência Brasileira afirma que a questão da democracia, no final da década de 20 e nos primeiros anos da década de 30 , vinha associada ao problema das raças, mais especificamente à raça negra. $\mathrm{O}$ regime forte era tido como o único propício às condições raciais que prevaleciam no Brasil. Fundado no princípio da superioridade racial dos brancos, o governo forte era mostrado como o único capaz de dirigir uma nação de mestiços.

A defesa do autoritarismo era feita, nos anos 30 , em nome de uma dada democracia. Oliveira Vianna e Azevedo Amaral defendiam a criação de um Estado que fosse autoritário e democrático ao mesmo tempo. Até mesmo o integralismo dizia-se incumbido de implantar no Brasil a verdadeira democracia e esta era oposta à democracia liberal. Plínio Salgado afirmava que a democracia integralista era a única que poderia salvar o Brasil do bolchevismo e do capitalismo internacional, ligado secretamente a Moscou (MARTINS, 1978, p. 70).

Azevedo Amaral, também crítico da democracia liberal como Oliveira Vianna, argumentava que era possível um regime autoritário compatível com as instituições democráticas não-liberais, afirmando em A Aventura Política do Brasil, de 1935, que a democracia liberal era um cadáver.

No capítulo "Autoridade e liberdade" do livro O Estado Autoritário e a Realidade Nacional (AZEVEDO AMARAL, 1981) encontram-se sistematizadas as principais idéias de Azevedo Amaral sobre democracia, liberdade, igualdade, autoridade e Estado autoritário. Em termos gerais, ele estava preocupado em mostrar que a democracia liberal não se ajustava à realidade brasileira devido ao modo como ela concebia a liberdade individual, pois, para ele, "sobrepujando, porém, essas relações individuais está o bem coletivo, diante do qual nenhuma liberdade e nenhum direito podem subsistir"(AZEVEDO AMARAL, 1981, p. 150).

O Estado que prevalecia no Brasil naquela época (Estado Novo) era, para A.Amaral, autoritário e democrático ao mesmo tempo, afirmação que ele justifica a partir de uma noção de liberdade incompativel com 0 conceito de igualdade. "Julgamos ter demonstrado que a idéia de igualdade não é essencial (...) à democracia" (AZEVEDO AMARAL, 1981, p. 157). É importante destacar que para ele a interpretação do verdadeiro sentido da democracia restaurava o prestígio do autoritarismo. O Estado autoritário era, para ele, um órgão de criação da verdadeira democracia, o que significava o início da construção do Brasil.

Ressalte-se que para Azevedo Amaral era necessário reestruturar o conceito de autoridade, uma vez que este tinha se desvirtuado pelos enxertos que historicamente foram feitos na doutrina da democracia. O Estado autoritário proposto, dizia ele, não guarda nenhum parentesco com as formas da democracia liberal. Pelo contrário, era preciso romper este círculo no qual o país teria ficado detido durante um século.

Era preciso se desvencilhar da ideologia liberaldemocrática, para que a nova organização nacional, afirma Azevedo Amaral, se tornasse rigorosamente uma "democracia autêntica", na medida em que ganharia sincronia com o ritmo do pensamento democrático nas suas mais puras e elevadas expressões. (AZEVEDO AMARAL, 1981, p. 102).

Azevedo Amaral afirma em 0 Estado Autoritário e a realidade nacional que inúmeras perversões foram enxertadas na doutrina da democracia, dentre elas: eleição direta, temporariedade dos mandatos, restrições da autoridade executiva, ficção da divisão dos poderes, etc., o que teria resultado numa mentalidade pseudodemocrática.

A representação, argumenta ele, é um postulado fundamental da democracia. No entanto, afirma que a representação é algo diferente das modalidades técnicas adotadas na prática do sistema representativo. Não apenas no Brasil mas também em outros países, a eleição direta pelo sufrágio universal redundou na impossibilidade de praticar o sistema representativo (AZEVEDO AMARAL, 1981, p. 102-103).

O problema estaria, portanto, na extensão irracional do critério majoritário. A grande massa do eleitorado não tem meios para opinar conscientemente. E, assim, serve apenas para manobras daqueles que manipulam a política. Todos os defeitos da democracia liberal teriam assumido formas extremas no Brasil.

A representação, idéia preciosa da democracia liberal, teria servido somente para adulterações indisfarçáveis das instituições políticas no Brasil, afirma Azevedo Amaral. "Supor que a democracia se baseie na igualdade real e prática das unidades componentes do corpo social é uma idéia não somente ilusória em contradição com a realidade objetiva, mas também irreconciliável com o conceito de uma organização nacional concretizada na existência do Estado." (AZEVEDO AMARAL, 1981, p. 104).

Azevedo Amaral pode ser considerado um dos mais importantes adeptos, na década de 30 , da associação entre Estado forte e/ou autoritário e democracia. Defensor do Estado Novo como uma organização essencialmente democrática e a única capaz de permitir o desenvolvimento normal da democracia no Brasil.

É importante ressaltar que a idéia predominante nos anos 30 era a de associação entre governo forte e democracia. O movimento "A Bandeira", que surgiu em 1936, defendia a necessidade de fundar uma democracia tipicamente brasileira dentro desta perspectiva

As reflexões em torno da democracia continuaram seguindo um caminho inusitado nas décadas 
seguintes. Os livros de Gilberto Freyre, escritos nas décadas de 30, 40 e 50 (Casa-Grande e Senzala, Interpretação do Brasil, Aventura e Rotina e Ordem e Progresso) mesmo sendo expressões de uma reação contrária às idéias que prevaleciam naquela época, como as de Oliveira Vianna, também ajudavam a cristalizar uma concepção de democracia associada à autoridade.

Para Gilberto Freyre, a democracia no Brasil era possível devido à democracia racial e a uma forma de domínio que se cristalizou na nossa tradição pautada no senso de autoridade e de dever e não no autoritarismo (FREYRE, 1981).

A noção de democratização da vida social aparece em Gilberto Freyre como resultado de "um processo de equilíbrio de antagonismos" (FREYRE, 1961, p. 53). Em termos gerais, o antagonismo principal, cujo equilíbrio embasou a democratização da vida social, foi o do senhor e do escravo.

"Entre essas duas misticas - a da ordem e a da liberdade, a da autoridade e a da democraciaé que se vem equilibrando entre nós a vida politica, precocemente saída do regime de senhores e escravos. Na verdade, o equilibrio continua a ser entre as realidades tradicionais e profundas: sadistas e masoquistas, senhores e escravos, doutores e analfabetos, indivíduos de cultura predominantemente européia e outros de cultura principalmente africana e amerindia" (FREYRE, 1961, p. 52).

A singularidade da democracia em Gilberto Freyre é que ele a concebe centrada numa forma de domínio pautada em relações domésticas ou privadas, ou seja, numa forma de domínio patriarcal que se define numa relação não-pública, na qual todos os sustentáculos do mando são privados e se definem no âmbito da família.

Gilberto Freyre demonstrava em Casa Grande e Senzala que existiam elementos não-palpáveis, não-visíveis que são definidores de uma identidade nacional e preexistentes a uma dada organização política, concepção que o diferenciava completamente de Oliveira Vianna, por exemplo.

"Até que o que havia de mais renitentemente aristocrático na organização patriarcal de família, de economia e de cultura foi atingido pelo que sempre houve de contagiosamente democrático ou democratizante e até anarquizante, no amalgamento de raças e culturas." (FREYRE, 1961, p. 355).

A democracia racial expressava a miscigenação como um dado positivo resultante de um padrão cultural que permite uma dada plasticidade. A raiz desse caráter miscigenário, afirma Freyre, torna-se o núcleo de nossa identidade nacional e assume um importante papel na democratização social brasileira.
A questão da democracia em Gilberto Freyre só pode ser entendida tendo em vista a relação de domínio. Ele faz, a todo momento, uma distinção entre autoridade/dever e autoritarismo. Isto é um dado chave em todas as suas discussões sobre a questão do domínio e define uma certa compreensão de democracia.

Gilberto Freyre demonstrava que nas condições sociais, políticas e culturais que aqui prevaleciam, havia uma fusão harmoniosa de tradições diversas no Brasil, principalmente no campo da cultura, como também "em vários sentidos sociais" em que imperava um regime dos mais democráticos, flexíveis e plásticos.

A pergunta que deve ser colocada é a seguinte: qual o significado da democracia numa forma de domínio centrada em relações domésticas e privadas? Ou seja, qual o sentido da democracia em que todos os sustentáculos do mando são privados e se definem no âmbito da família? Para Gilberto Freyre, a democracia não está ligada à publicização das relações sociais. Daí a possibilidade de concebê-la nas condições de domínio patriarcal.

No livro Nordeste (FREYRE, 1967) há evidências de que para Gilberto Freyre, dado o padrão cultural permissivo, há uma simultaneidade entre 0 padrão democrático e o padrão aristocrático, ou seja, eles não são excludentes. Assim, é possível compreender em Interpretação do Brasil (FREYRE, 1947) sua definição de aristocracia democrática: aquela que não impedia que qualquer homem, independentemente de raça ou cor, se associasse a ela. Era a combinação, para ele, de métodos politicamente aristocráticos com maneiras e costumes democráticos.

A questão básica indicada em alguns de seus textos como, por exemplo, Sobrados e Mucambos, que contém um estudo sobre o mulato e sua ascensão na sociedade patriarcal, é a aceitação de que a saída de uma ordem aristocrática para uma ordem democrática não implicava em destruição da primeira em favor da segunda, e sim em um processo de conciliação entre as duas (FREYRE, 1959, p. cap 1 e 2).

Os livros Sobrados e Mucambos e Ordem e Progresso tornam evidentes que, para Gilberto Freyre, as noções de equilíbrio e conciliação são os fundamentos da democracia. Ao pensar a democracia em termos de acomodação social, ele deixa evidenciado que os agentes portadores da democracia eram aqueles que conseguiam estabelecer a integração e $o$ equilíbrio. $O$ mulato e $o$ bacharel seriam, então, agentes de democracia para Gilberto Freyre.

Em síntese, para ele, a democracia étnica e social que se desenvolveu no Brasil foi produto de vários fatores que abrangem a forma de domínio, os aspectos sociais e culturais presentes na nossa 
formação social e um conjunto de forças sociais que equilibravam as diferenças e os antagonismos.

Enquanto Gilberto Freyre elaborava uma análise mistificadora do passado no trato da questão da democracia, Sérgio Buarque de Holanda, também nos anos 30, propunha uma análise baseada na desmistificação do passado em Raizes do Brasil.

A partir de uma perspectiva teórico-analítica distinta, Sérgio Buarque de Holanda ressaltava a ausência de bases sociais para a existência da democracia. De maneira aposta, G.Freyre lutava para delinear as condições que favoreceram a existência de uma democracia social e racial no Brasil.

Sérgio Buarque de Holanda combateu veementemente, em Raizes do Brasil, a falsa democracia de bases subvertidas que se defendia no Brasil. Ao contrário de Gilberto Freyre, que ressaltava os traços oligárquicos do passado como elementos que não desfavoreciam a existência da democracia, o autor de Raízes do Brasil afirmava que esses elementos eram totalmente desabonadores e através dos tempos vinham maculando qualquer possibilidade de democratização da vida social.

No cap. 7 da obra supra citada, Sérgio Buarque de Holanda deixava claro que apenas uma transformação revolucionária do presente poderia criar as condições indispensáveis para que a democracia deixasse de ser apenas uma fachada. $O$ conhecimento do passado deveria ser utilizado para derrotar os elementos autoritários e excludentes da vida política e social brasileira e jamais para justificar a sua permanência.

As concepções político-autoritárias reinantes na década de 30 foram duramente criticadas por Sérgio Buarque de Holanda. Desde os primeiros capítulos de Raízes do Brasil havia uma denúncia da possibilidade de persistência do autoritarismo numa sociedade que se modernizava lentamente no plano econômico e social. A modernização política (AVELINO FILHO, 1987, p. 33-41), no entanto, parecia absolutamente dificil numa sociedade que tinha se firmado sobre as bases da exclusão.

Sérgio Buarque de Holanda afirmava que a democracia só vingaria entre nós se fosse derrotada a mentalidade senhorial que impregnava os valores, os costumes, as atitudes e as instituições sociais e políticas. O modo de ser oligárquico permanecia como uma nódoa que dificultava grandemente a construção de uma sociedade fundamentada na publicização das relações sociais.

Diferentemente de Gilberto Freyre, Sérgio B. de Holanda considerava o nosso passado oligárquico responsável pela extrema dificuldade encontrada para democratizar o Brasil. A defesa de uma revolução vertical (cap.7, de Raízes do Brasil) tinha o objetivo de demonstrar que as bases da democracia tinham que ser criadas não a partir de nosso passado oligárquico, mas apesar dele.
O traço marcante do sistema político oligárquico brasileiro sempre foi 0 nítido desprezo pelas classes populares, assinala Sérgio Buarque de Holanda (HOLANDA, 1976, p. 4) e nenhuma democracia pode estabelecer suas bases a partir dessas condições de exclusão social. É necessário, portanto, subvertê-las.

Sem quebrar a iniqüidade oligárquica, por exemplo, a democracia continuaria sendo um lamentável mal-entendido. Em entrevista de 1976, Sérgio B.de Holanda explicava que "a idéia básica (em Raizes do Brasil) era a de que nunca teria havido democracia no Brasil, e de que necessitávamos de uma revolução vertical, que realmente implicasse na participação das camadas populares. Nunca uma revolução de superfície, como foram todas na História do Brasil, mas uma que mexesse mesmo com toda a estrutura social e política vigente" (HOLANDA, 1976, p. 3).

Em Herança rural (cap. 3 de Raízes do Brasil) a preocupação básica é destacar as mudanças de superficie que ocorreram no século XIX, isto porque "enquanto perdurassem intatos e, apesar de tudo, poderosos, os padrões econômicos e sociais herdados da era colonial e expressos principalmente na grande lavoura servida pelo braço escravo, as transformações mais ousadas teriam de ser superficiais e artificiosas" (HOLANDA, 1987, p. 46).

Para Sérgio Buarque de Holanda, as nossas raízes políticas (HOLANDA, 1957) eram totalmente desabonadoras. O grupo familiar não conhecia restrição, o pátrio poder era ilimitado, a entidade privada sempre prevalecia. Ressalte-se que esta invasão do público pelo privado e do Estado pela família foi internalizada pelos diversos segmentos sociais, encontrando-se aí a dificuldade de rompimento de um princípio de autoridade que se assenta em relações privadas. "Estereotipada por longos anos de vida rural, a mentalidade de casa-grande invadiu assim as cidades e conquistou todas as profissões, sem exclusão das mais humildes" (HOLANDA, 1987, p. 55-56).

Observe-se que, em Sérgio Buarque de Holanda, a questão da democracia coloca-se como ponto central de uma tensão constante entre o padrão de organização social e a forma de dominação política. Ressalte-se que ele não dissocia organização social da cultura. Daí a necessidade de pensar a democracia in concreto, ou seja, tendo em vista uma dada forma de organização social, seus padrões de domínio e de cultura.

O cap. 5 de Raízes do Brasil, intitulado "O homem cordial, é talvez o momento mais evidente da supremacia de uma mentalidade rural que contaminou todos os aspectos da vida social. George Avelino Filho (AVELINO FILHO, 1987, p. 37) afirma que esta relação de cordialidade se define em função da inexistência de espaços impessoais que são básicos para a organização da esfera públi- 
ca. Há um desvirtuamento da comunidade política para a comunidade doméstica.

O predomínio de relações familiares na sociedade brasileira, afirma Sérgio B.de Holanda, teria sido responsável pela não-criação de bases para a democracia. A formação em ambientes patriarcais levou à dificuldade de entender a distinção entre 0 domínio público e o domínio privado. As relações que engendram o homem cordial situam-se na esfera do íntimo, do familiar, do privado.

A cordialidade como um traço ativo e fecundo do caráter brasileiro define padrões de convivio humano que se constituem em imensos obstáculos para a construção de um outro padrão de convívio: o democrático. É como se o individuo se defendesse da publicização das relações sociais; o que torna precária a possibilidade de luta por ideais abstratos e subjetivos.

Desta forma, Sérgio Buarque de Holanda afirma que as normas particularistas se estabeleceram na sociedade brasileira e funcionam como entraves para o desenvolvimento de instituições políticas, fundadas em princípios neutros e abstratos, condizentes com uma sociedade que se democratiza.

No cap. 6 de Raízes do Brasil, intitulado Nosso Tempo, a democracia aparece como uma forma de cultura, ou seja, é a internalização de valores condizentes com um modo de vida diferente daquele que se caracteriza pelo apego a um ethos personalista configurado pelo recinto doméstico. Esse personalismo individual não se submete facilmente a um sistema democrático.

A dificuldade de implantação da democracia no Brasil só seria vencida com o rompimento do enorme abismo que havia entre a vida social e a vida política. Este era o grande desafio dos novos tempos. A separação entre vida social e vida política, responsável pela ausência de condições para a existência da democracia, era engendrada e engendrava ao mesmo tempo o alheamento da política como algo culturalmente presente no espírito do brasileiro; o que demonstra, segundo Sérgio Buarque de Holanda, que não faltavam apenas bases sócio-políticas mas também culturais para a democratização.

A existência de figurantes mudos é a negação da democracia para o autor em questão. É produto de um abismo entre as elites dirigentes e a massa. Esse processo leva à eternização de um dado sistema de domínio que impede o surgimento de novos caminhos, ou seja, novas formas sociais não excludentes.

$\mathrm{O}$ artigo $\mathbf{O}$ poder pessoal objetiva elucidar a distância existente entre a elite e os figurantes mudos, tanto no império quanto na república. A análise das bases de sustentação política da oligarquia, nestes dois períodos, mostra que a preservação do interesse local, a manutenção de uma autoridade tutelar e a imperfeição do sistema eleitoral mantinham o processo de exclusão (HOLANDA, 1972 , p. 78).

Sérgio Buarque de Holanda afirma que a ineficácia do sistema representativo denunciava a falta de bases reais para a democracia, tanto no império quanto na república. Nos rituais da vida política floresceu "o costume de absorver desentendimentos e conflitos numa urdidura cerrada de conchavos e de compromissos intra-muros, que impediam facções e conflitos de tomarem proporções políticas ameaçadoras. É o seu modo de reexplicitar o sentido da cordialidade nos costumes políticos brasileiros, oligárquicos, pessoais, fechados e capazes de transcenderem a violência quotidiana sob uma aparência de harmonia, que confirmava o peso do controle social e político exercido por minorias extremamente reduzidas." (DIAS, 1985, p. 52-53).

Em A democracia improvisada, cap. 2 de História Geral da Civilização Brasileira (t.2,v.5), e em Nossa revolução, último capítulo de Raízes do Brasil, Sérgio Buarque de Holanda mostra como a falta de bases para o sistema representativo, bem como a sua distorção, tanto no império quanto na república, serviram para a cristalização de uma democracia de fachada que foi se modificando e se reelaborando no decorrer da história política brasileira.

No Brasil, desde seus primórdios, faltou o elemento que em toda parte constituiu o nervo das democracias: um sistema representativo digno desse nome. Para S.B.de Holanda, a questão sempre foi: qual a base para a representação que existiu no Brasil? Sempre se produziram as condições, em todos os momentos, para a distorção cada vez mais acentuada dos princípios democráticos. Está na base desse processo a elitização e a oligarquização do poder impregnadas como uma nódoa na política brasileira.

Os diversos elementos que foram levantados deixam evidente que, para Sérgio Buarque de Holanda, a transformação complexa e verdadeira na estrutura da vida social passa por todas as esferas: econômica, social, política e cultural. A democracia é uma forma de cultura, de valores. No entanto, é fundamental o papel das instituições, pois, para ele, há uma relação de complementaridade entre as bases políticas e culturais na realização da democracia.

A revogação de uma ordem moral, social e política seria possível através de mudanças radicalmente democráticas que deveriam ser absolutamente diferentes de todas as mudanças anteriores, na medida em que estariam marcadas pela verticalidade. Em síntese, para o autor de Raízes do Brasil, a democracia que nunca tinha existido de fato no Brasil, poderia ser alcançada se o processo de sua constituição fosse popular. Esta seria a nossa revolução que poderia romper, nos planos político 
e cultural, com o dilema entre cordialidade e democracia.

As inúmeras discussões acerca da democracia prosseguem nas décadas de 40 e 50 . A denominada redemocratização do país, a partir de 1945 , suscitou diversas indagações sobre as especificidades da política brasileira bem como sobre as suas possibilidades.

Florestan Fernandes, no artigo Existe uma crise da democracia no Brasil?, escrito a partir de uma conferência de 1954, faz uma ampla reflexão sobre as duas correntes principais que pensavam a problemática da democracia no Brasil. Uma estabelecia um confronto entre os critérios formais de reconhecimento da democracia e a realidade política vigente (Alberto Torres, Azevedo Amaral, Oliveira Vianna, etc.). A outra fazia uma análise das tensões entre a ordem legal e a ordem criada pelos costumes e até que ponto esta última restringia a plena vigência dos princípios democráticos (Nestor Duarte, Nunes Leal, Sergio B. de Holanda e Caio Prado Júnior) (FERNANDES, 1979, p. 94).

A preocupação básica de Florestan Fernandes era pensar a questão da democracia, na década de 50 , à luz das condições sociais reinantes naquele momento. É um texto significativo à medida que esclarece as diversas posições acerca da crise da democracia. Dentre elas, ele destaca: as que acreditavam que a mesma resultava do processo de crescimento econômico daquele momento, as que situavam a crise no plano moral e até aquelas que explicavam a crise da democracia pela incompetência das elites brasileiras.

Havia necessidade, dizia F.Fernandes, de precisar o sentido da afirmação de que a ordem legal brasileira tendia para um padrão organizacional democrático; uma vez que era preciso tomar a democracia no Brasil como algo em elaboração sócio-cultural e que, por isso, não tinha atingido ainda a maturidade política

$E$ as dificuldades para se atingir essa maturidade eram enormes, pois o "Brasil se constituiu em Nação, econômica, cultural e socialmente, em condições altamente desfavoráveis à difusão de ideais democráticos de vida política." (FERNANDES, 1979, p. 99) Desta forma, o que aparece, observa Fernandes, como crise da democracia é, na realidade, a lentidão que vem marcando o processo de substituição de antigas práticas e hábitos, por outros novos e mais compativeis com a ordem democrática que está em elaboração.

A dificuldade na elaboração sócio-cultural da democracia, segundo Florestan Fernandes, ligavase naquele momento (década 1950) a algumas questões básicas, como: a forma de mudança lenta e desigual da sociedade brasileira se constituía num entrave para a constituição de hábitos e atitudes democráticos; a situação econômica não favorecia esse processo; e outro elemento desfavorável era a elite e seu pouco interesse em resolver os problemas atinentes a uma nova ordem política e democrática.

"Mas pensamos que, no periodo de transição que atravessamos, seria conveniente adotar uma estratégia que permitisse, nos quadros sociais existentes na sociedade brasileira, intensificar as pressões e os controles sociais sobre as atividades do governo. Se isso não for conseguido, subsistirá o divórcio entre o Estado e a Nação, com todos os perigos que lhe são inerentes, alertava Florestan Fernandes." (FERNANDES, 1979, p. 106).

\section{Referências Bibliográficas}

AVELINO FILHO, G. As raizes de "Raízes do Brasil". Novos Estudos Cebrap, São Paulo, n. 18 , p. 33-41, set. 1987.

AZEVEDO AMARAL. 0 Estado autoritário e a realidade nacional. Brasília: Câmara dos Deputados/UNB, 1981.

BEIGUELMAN, P. Joaquim Nabuco. São Pau10: Ática, 1982.

CARDOSO, V. L. À margem da história do

Brasil. São Paulo: Nacional, 1979.

DIAS, M. O. L. da Silva (Org). Sérgio Buarque de Holanda. São Paulo: Ática, 1985. p. 52-53.

(Col. Gdes.Cientistas Sociais; n.51).

FAORO, R. Romance sem heróis. Veja, São Paulo, n.399, p.6, 28 abr. 1976.

Os donos do poder. Rio de Janeiro, Globo, 1989. v. 2

FERNANDES, F. Existe uma crise da democracia no Brasil? In Mudanças Sociais no Brasil. São Paulo: Difel, 1979.

FREYRE, G. Interpretação do Brasil. Rio de Janeiro, J.Olympio, 1947.

FREYRE, G. Casa-Grande e Senzala. Rio de Janeiro, J.Olympio, 1981. t.1.

FREYRE, G. Nordeste. Rio de Janeiro: J. Olympio, 1967

FREYRE, G. Sobrados e Mucambos. Rio de Janeiro: J. Olympio, 1961. t.2.

FREYRE, G. Ordem e Progresso. Rio de Janeiro: J. Olympio, 1959. t.1.

HOLANDA, S. B de (org). História geral da civilização brasileira. São Paulo, Difel, 1960 [1964, 1972], t.1,v.2; t.2,v.2; t.2,v.5. A democracia é difícil. Veja, São

Paulo, n. 386, p. 4, 28, jan., 1976.

O poder pessoal. In História Geral

da Civilização Brasileira; O Brasil Monárquico; Do Império à República. São Paulo, Difel, 1972. t.2, v.5, livro 2 . 
Monções. São Paulo, Alfa-ômega,

1976.

de Raizes do Brasil. Rio de Janeiro,

J.Olympio, 1987.

Caminhos e fronteiras. Rio de

Janeiro, J.Olympio, 1957.

MARTINS, W. História da inteligência brasileira. São Paulo, Cultrix, Edusp, 1978. v.6 História da inteligência brasileira.

São Paulo, Cultrix, Edusp, 1978a. v.7

NABUCO, J. Campanha abolicionista no Recife. Rio de Janeiro: Typ. Leuzinger, 1885. Campanha de imprensa: 1884-1887.

In: Obras completas. São Paulo, Instituto Progresso Editorial, 1949.

Minha formação. Rio de Janeiro:

J.Olympio, Brasília, 1976.

O abolicionismo. Petrópolis, Vozes,

Brasília, 1977. v.7.

NOGUEIRA, M. A. As desventuras do libera-

lismo. Rio de Janeiro: Paz e Terra, 1984.
OLIVEIRA VIANNA, F. J. de. O idealismo da evolução política do império e da república. São Paulo, Biblioteca d'O Estado de São Paulo, 1922.

Populações meridionais do Brasil. Brasília: Câmara dos Deputados, 1982. Instituições Políticas Brasileiras.

Belo Horizonte: Itatiaia, 1987. [s/ed], 1927.

O Idealismo na Constituição. [s/l]

PÉCAUT, D. Os intelectuais e a política no

Brasil. São Paulo: Ática, 1990.

PRADO JUNIOR, C. Evolução política do Brasil: Colônia e império. São Paulo: Brasiliense, 1987

TORRES, A. S de Martins. A organização nacional. São Paulo: Nacional, 19.78.

TORRES, J. C. de Oliveira. A democracia coroada. Rio de Janeiro: J.Olympio, 1957. 